\title{
Influence of the genetic pattern and sex of mice in experimental lagochilascariosis
}

\author{
M. F. S. PRUDENTE, J. G. FREITAS, E. L. RIBEIRO, M. S. CARVALHAES
}

Department of Microbiology, Immunology, Parasitology and Pathology, Institute of Tropical Pathology and Public Health, Federal University of Goiás, Goiânia - Brazil, E-mail: msilvia@iptsp.ufg.br

\begin{abstract}
Summary
We studied experimental lagochilascariosis in male and female mice of four strains. The survival ratio and number of larvae recovered varied: B10.A and C57BL/6 mice had the highest number of larvae 90 days after infection and the lowest survival ratio at 345 days of infection. BALB/c mice had an intermediate survival ratio and number of larvae. A/J mice had the lowest number of larvae and the highest survival ratio. Our findings suggest that resistance to Lagochilascaris minor is not linked to the $\mathrm{H}-2^{\mathrm{a}}$ region because both susceptible B10.A and resistant $\mathrm{A} / \mathrm{J}$ mice express the $\mathrm{H}-2^{\mathrm{a}}$ haplotype. However, the pattern of mortality and larvae recovered that we observed in C57BL/6 mice, which possess the same genetic background as B10.A, indicates that the background genotype does affect the outcome of lagochilascariosis in mice. This study demonstrates that the genetic background, but not $\mathrm{H}-2^{\mathrm{a}}$ or sex, determine the outcome of lagochilascariosis in mice.
\end{abstract}

Key words: Lagochilascaris minor; helminth; sex; MHC; H-2

\section{Introduction}

The nematode Lagochilascaris minor is the etiological agent of human lagochilascariosis. In addition to humans, L. minor infection has been described in domestic felines and in dogs. Human L. minor-infection takes place after ingestion of raw or inadequately cooked meat from wild animals harboring encysted larvae of the parasite. The parasite has been found in the lung, central nervous system, cervical region and pharynx, leading to the formation of nodular lesions. These lesions, which can open, may contain eggs, larvae and adult worms. Clinical signs of the disease seem to depend on the number of $L$. minor present and tissue localization, as well as the host immune response (Fraiha et al., 1989; Campos et al., 1992).

The capacity of $L$. minor to migrate across different human tissues has also been observed in animal models of the disease such as mice and cats (Sakamoto \& Cabrera, 2002). In mice orally inoculated with the parasite eggs, after the process of hatching, third stage larvae (L3) migrate through the intestinal mucosa, reaching vessels and hepatic parenchyma. They then disseminate to other tissues such as lungs, skeletal muscles and subcutaneous tissues (Semerene et al., 2004). In cats inoculated with carcasses of infected mice, L3 migrate through the esophagus, pharynx, trachea, rhino and oropharynx, and cervical lymph nodes. The larvae develop into L4 and adult parasites, and can release in the upper digestive tract, perpetuating the cycle (Paço et al., 1999; Volcan et al., 1992).

The development of an ideal host parasite model is a prerequisite for research on any aspect of lagochilascariosis. L. minor does not complete its full developmental cycle in the mouse. The establishment and survival of helminth parasites in potential hosts is influenced by many factors. Host genetic factors have a major influence on the susceptibility of mammals to infection by a variety of microorganism (Gupta et al., 2003). The genetically determined differences between individuals in a population affect the efficiency of the immune response, and thus the host phenotype of susceptibility. The inbred strains of mice present different $\mathrm{H}-2$ haplotypes and each strain has a specific collection of alleles within the MHC loci. Some of these strains share the same H-2 haplotype, but express different genetic backgrounds (Junqueira-Kipnis, 1999). The influence of $\mathrm{H}-2$ molecules on the immune response was shown by the infection of mice with Trichinella spirallis (Dick et al., 1988; Wakelin et al., 1986). H-2 linked as well as non-H-2 linked genes contribute to the immune response, which affects the expulsion of the nematode from inbred and congenic mice.

Singer-Vermes et al. (1995) demonstrated that the sex of the host affects the severity of experimentally induced paracoccidioidomycosis in mice of a susceptible strain 
(B10.A), but not in a resistant one (A/Sn). Examination of the helmintic parasitic burden in mice revealed differences between the sexes within the same genotype for Syphacia obvelata, Heligmosomoides polygyrus and Aspiculurus tetratera infection in mice (Vasconi et al., 2008). Progesterone, through its metabolism to estradiol, affects the establishment, growth and reproduction of Taenia crassiceps in mice (Vargas-Villavivencio et al., 2005). In fact, in many vertebrate species, males tend to exhibit higher rates of parasite infection than females. Sex-associated hormones may influence immunocompetence and are hypothesised to lead to this bias, as in Rupicapra rupicapra infection (Hoby et al., 2006).

In the present study, we sought to evaluate the susceptibility of male and female mice of various inbred strains to experimental lagochilascariosis. We chose strains with different H-2 histocompatibility complex genes, and different genetic backgrounds. Susceptibility was measured by survival and number of larvae recovered.

\section{Materials and methods}

\section{Mice}

Six- to ten-week old B10.A male and female mice were purchased from the University of São Paulo Animal Facility. A/J male and female mice were kindly supplied by the Instituto Butantan, and BALB/c and $\mathrm{C} 57 \mathrm{BL} / 6$ mice were from the animal house of Federal University of Goiás. They were given food and water "ad libitum" and handled according to the local regulations. The Research Ethics Committee of the Federal University of Goiás approved the research protocols.
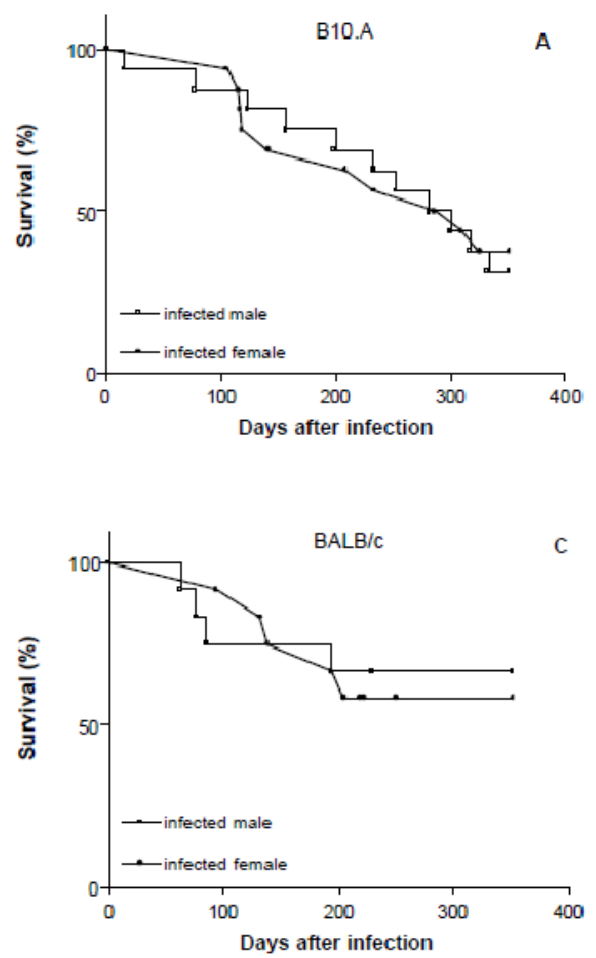

\section{Parasites}

Parasite eggs were collected from the faeces of Felis domesticus experimentally infected with a human isolate of L. minor. Faeces from infected animals were submitted to Hoffman's method and kept in culture in formalin solution (1\%) at room temperature for 30 days. After the development of infective eggs containing third-stage larvae, cultures were submitted to Faust's method for optimal recovery of eggs free from faecal debris (Oliveira et al., 2002). Egg suspensions were exhaustively washed with phosphate buffered saline ( $\mathrm{pH} 7.4$ ); transferred to a graduated centrifuge tube, and the eggs were then counted on microscope slides. The final concentration was adjusted to $10^{4}$ eggs $/ \mathrm{ml}$ and used to infect the mice.

\section{Experimental infection design}

A total of forty-four B10.A (H-2 ${ }^{\mathrm{a}}$, twenty-two male and twenty-two female), twenty-six C57BL/6 (H-2 ${ }^{\mathrm{b}}$, thirteen male and thirteen female), twenty-four BALB/c (H-2 ${ }^{\mathrm{d}}$, twelve male and twelve female) and twenty-eight A/J (H$2^{\mathrm{a}}$, fourteen male and fourteen female) mice were orally inoculated with a suspension of $2 \times 10^{3} \pm 200$ L. minor eggs per animal. As controls we utilized thirteen B10.A (fifty male and fifty female), twenty-six C57BL/6 (thirteen male and thirteen female), twenty-two BALB/c (eleven male and eleven female) and twenty $\mathrm{A} / \mathrm{J}$ (ten male and ten female). For each strain, the animals were followed for one year to determine survival rates. An additional group of ten infected mice of each strain (five male and five female) was sacrificed 90 days after infection to determine the number of skeletal nodules containing larvae (each nodule has only one larvae).
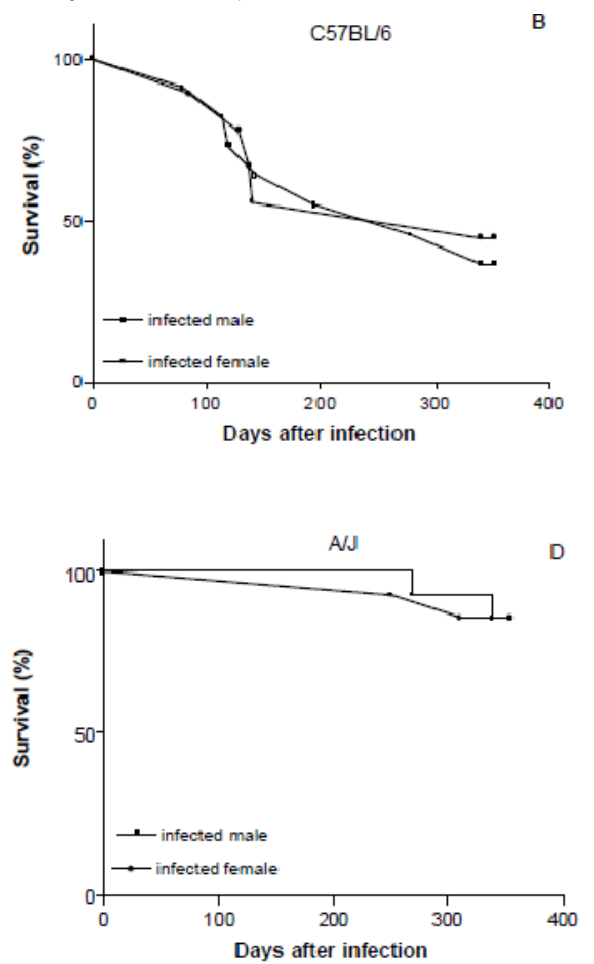

Fig.1. Cumulative survival rates during the period post infection of male $(\square)$ and female $(\bullet)$ mice that had been orally inoculated with 2000 viable 


\section{Statistical analysis}

The numbers of recovered larvae are expressed as means and standard deviations, and data were analysed by the Mann-Whitney test. Survival ratios were obtained using the program Prism 4.0 and the survival curves were compared by Log-Rank post-test. The $p$ values $<0.05$ were considered statistically significant.

\section{Results}

B10.A infected males survived an average of 290.5 days, reaching $22.7 \%$ of survival on day 345 . Infected females survived an average of 297.5 days, reaching $27.2 \%$ survival on day $345(\mathrm{p}=0.24)$ (Fig. 1A). The C57BL/6 infected males and females survived an average of 278 and 241 days respectively, both reaching $30.7 \%$ survival 345 days after infection $(\mathrm{p}=0.62)$ (Fig. 1B). BALB/c infected males and females survived over 345 days, reaching $66 \%$ and $58.3 \%$ survival on day 345 , respectively $(p=0.34)$ (Fig. 1C). A/J infected males and females displayed the highest survival ratio after 345 days of infection, $85.7 \%$ for both sexes, and average survival time of over 345 days $(\mathrm{p}=0.9)$ (Fig. 1D). We did not observe statistically significant differences in the survival of male and female mice from each lineage $(p>0.05)$. In addition, only one or two non-infected animals from all lineages died during the period of study.

No differences were noted in the mortality ratio of B10.A $\mathrm{x}$ C57BL/6 $(\mathrm{p}=0.27), \mathrm{BALB} / \mathrm{c} \times \mathrm{C} 57 \mathrm{BL} / 6(\mathrm{p}=0.32)$ and $\mathrm{A} / \mathrm{J} \times \mathrm{BALB} / \mathrm{c}(\mathrm{p}=0.15)$ infected male mice. Nevertheless, we found significant differences in the mortality ratios of B10.A $\times$ BALB/c $(p=0.05), B 10 . A \times A / J ~(p=0.0002)$ and $\mathrm{C} 57 \mathrm{BL} / 6 \times \mathrm{A} / \mathrm{J}(\mathrm{p}=0.04)$ infected male mice (Fig. 2A).

Significant differences were observed in the mortality ratios of B10.A $\times \mathrm{BALB} / \mathrm{c}(\mathrm{p}=0.05), \mathrm{B} 10 . \mathrm{A} \times \mathrm{A} / \mathrm{J}(\mathrm{p}=$ $0.006), \mathrm{C} 57 \mathrm{BL} / 6 \times \mathrm{BALB} / \mathrm{c}(\mathrm{p}=0.04)$ and $\mathrm{C} 57 \mathrm{BL} / 6 \times \mathrm{A} / \mathrm{J}$ $(p=0.005)$ infected female mice. Nevertheless, no significant differences were observed in the mortality ratios of B10.A x C57BL/6 (p=0.65) and A/J x BALB/c $(p=0.18)$ infected female mice (Fig. 2B).

The numbers of $L$. minor recovered from superficial nodules of the skeletal musculature and subcutaneous tissues (each nodule containing one parasite) were similar in males and females of all isogenic strains of mice studied 90 days after infection. However, the number of recovered parasites from $\mathrm{BALB} / \mathrm{c}$ mice was lower than the numbers recovered from $\mathrm{C} 57 \mathrm{BL} / 6$ and $\mathrm{B} 10 . \mathrm{A}$ infected mice $(\mathrm{p}=$ $0.03) . \mathrm{A} / \mathrm{J}(\mathrm{p}=0.01)$ mice had a lower number of larvae when compared to $\mathrm{C} 57 \mathrm{BL} / 6$ infected mice. $\mathrm{A} / \mathrm{J}(\mathrm{p}=0.05)$ mice also had a lower number of larvae when compared to B10.A infected mice (Fig. 3).

\section{Discussion}

The first purpose of this study was to test the hypothesis of male biased parasitism, which is thought to arise because of different steroid hormone levels between the sexes in mice. Inbred strains of mice resistant to experimental lago-
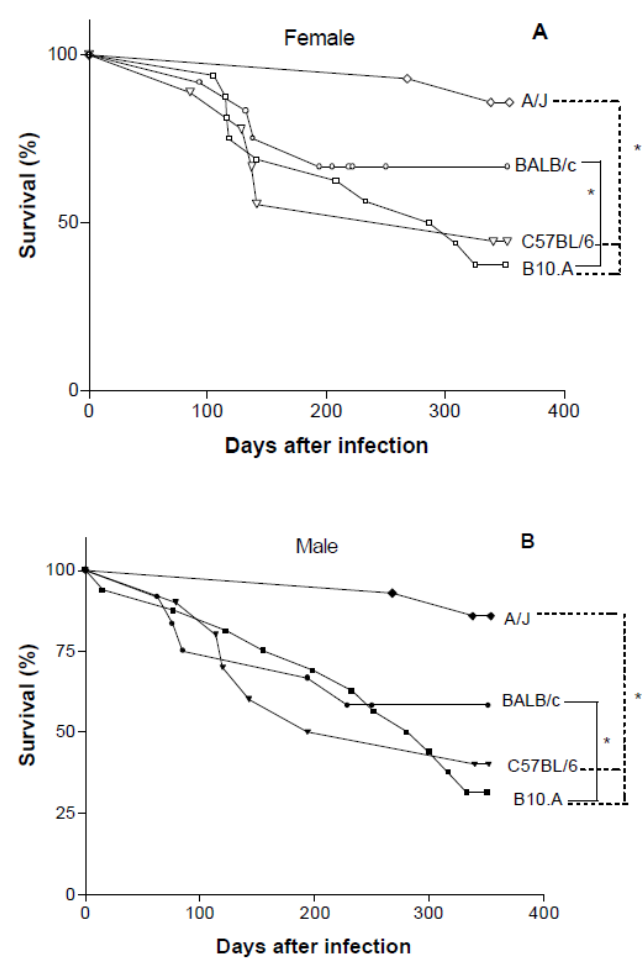

Fig.2. Cumulative survival rates during the period post infection of mice of different strains that had been orally inoculated with 2000 viable eggs of Lagochilascaris minor. Survival ratio of female (A) and male (B) mice was determined using the Kaplan-Meier test $(* \mathrm{p}<0.05)$.

chilascariosis, such as $\mathrm{A} / \mathrm{J}$, did not present differences linked to sex. Sensitive (B10.A and C57BL/6) and intermediate $(B A L B / c)$ lineages did present differences sexlinked differences, but they were not statistically significant. Therefore, the hypothesis of male biased parasitism was not confirmed on the basis of number of recovered L3 larvae and survival ratio, for experimental lagochilascariosis in mice.

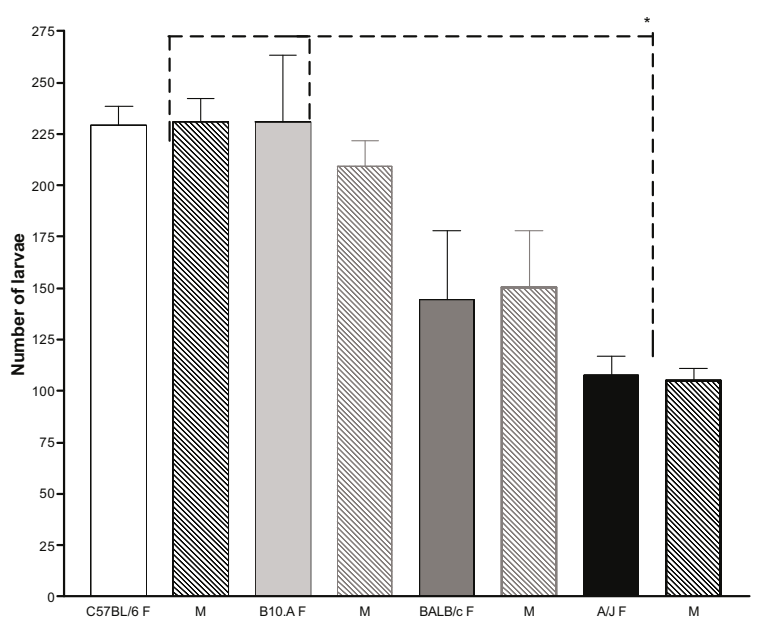

Fig.3. Number of larvae recovered from skeletal musculature and subcutaneous tissue of male and female C57BL/6, B10.A, BALB/c and $\mathrm{A} / \mathrm{J}$ mice inoculated with infective eggs and necropsied after 90 days of infection. Results are expressed as the average of five mice \pm SD. Statistical analysis of the differences was determined by Mann - Whitney test $(* \mathrm{p}<0.05)$. 
Experimental studies to determine the influence of genetics on resistance to parasites requires the use of genetically defined animal models and a research strategy in which several characteristics of the animals are analyzed. Suitable characteristics to discriminate susceptible from resistant animals must show clear differences between inbred strains. Besides the survival ratio of infected mice, other discriminatory parameters may be adequate, such as determination of the number of larvae recovered. We demonstrated in this study that the number of $L$. minor recovered from superficial nodules of the skeletal musculature and subcutaneous tissue of mice constituted a reliable parameter to discriminate susceptible from resistant mice. Measurement of cytokine levels, antibody production, macrophage activity and the development of lesions are currently being studied.

In this study we verified that B10.A mice orally infected with encysted larvae of $L$. minor were the most susceptible animals, since they showed the largest mortality ratio and the largest number of larvae recovered. The pattern of infection in C57BL/6 mice was similar to that presented by B10.A animals (survival ratio below $35 \%$ ). On the other hand, $\mathrm{A} / \mathrm{J}$ mice orally infected with infective eggs containing L3 larvae of L. minor were the most resistant animals, since they showed the lowest mortality ratio and the lowest number of larvae recovered (survival ratio above $80 \%$ ). $\mathrm{BALB} / \mathrm{c}$ infected mice appear to have intermediate susceptibility, with a survival ratio of $55-65 \%$.

Resistance to L. minor assayed by mortality and number of larvae recovered denoted that resistance is not linked to the $\mathrm{H}-2^{\mathrm{a}}$ region because both susceptible B10.A and resistant $\mathrm{A} / \mathrm{J}$ mice express the same $\mathrm{H}-2^{\mathrm{a}}$ haplotype. However, the pattern of mortality and larvae recovery of C57BL/6 mice, which present the same background genotype as B10.A, indicates that the genetic background affects the outcome of lagochilascariosis in mice.

This study clearly demonstrates that the genetic background, but not $\mathrm{H} 2^{\mathrm{a}}$ or sex, determine the outcome of lagochilascariosis in mice. Continued understanding of the factors that contribute to the outcome of lagochilascariosis will be possible, although the immune mechanisms underlying the pathogenesis of this helmintosis are still poor understood.

\section{Acknowledgement}

The authors would like to thank American Journal Experts for the English language review. This study was supported CNPq and FAPEG (grant 02/2007).

\section{References}

Campos, D. M. B., Freire-Filha, L. G., Vieira, M. A., PAÇO, J. M., MAIA, M. A. (1992): Experimental life cycle of Lagochilascaris minor Leiper, 1909. Rev. Inst. Med. Trop. Sao Paulo, 34: 277 - 287

ReCEIVED August 19, 2008
Dick, T. A., Dougherty, D. A., WAsson, D. L. (1988): Trichinella spiralis infections of inbred mice: genetics of the host response following infection with different Trichinella isolates. J. Parasitol., 74: $665-669$

FraiHA, H., LEÃo, R. N. Q., CostA, F. S. A. (1989): Lagochilascariase humana e dos animais domésticos. Vet. Int. Zoonoses, 1: 25 - 33

GuPta, R., Tyagi, K., JaIn, S.K., MisRa-Bhattacharya, S. (2003): Brugia malayi: establishment in inbred and outbreed strains of mice. Exp. Parasitol., 103: 57 - 60

Hoby, S., Schwarzenberger, F., Doherr, M. G., RoBERT, N., WALZER, C. (2006): Steroid hormone related male biased parasitism in chamois, Rupicapra rupicapra rupicapra. Vet. Parasitol., 138: 337 - 348

JUNQUEIRA-KIPNIS, A. P. (1999): Contribuição dos modelos murinos para o estudo da paracoccidioidomicose. Rev. Patol. Trop., 24: $14-19$

Oliveira, J. A, Barbosa, C. L., Vieira, M. A, PaÇo, J. M., Carrijo, A. S., Fiorini, M. P., Campos, D. M. B. (2002): Isolado de Lagochilascaris minor: procedimentos para obtenção de ovos infectantes. Rev. Patol. Trop., 31, $121-128$

PaÇo, J. M., Campos, D. M. B., Araújo De Oliveira, J. (1999): Wild rodents as experimental intermediate hosts of Lagochilascaris minor Leiper, 1909. Mem. Inst. Oswaldo Cruz, 94: 441 - 449

Sakamoto, T., Cabrera, P. A. (2002): Subcutaneous infection of Lagochilascaris minor in domestic cats from Uruguay. Vet. Parasitol., 108: 145 - 152

Semerene, A. R., Lino Junior, R. S., Araúuo De Oliveira, J., Magalhães, A V., Stefani, M. M. A, Barbosa, A. P., CAMpos, D. M. B. (2004): Experimental lagochilascariosis: histopathological study of inflammatory response to larval migration in the murine model. Mem. Inst. Oswaldo Cruz, 99: 393 - 398

Singer-Vermes, L. M., Sakamoto, T. N., Vaz, A. A. C., CALICH, V. L. G. (1995): Influence of the genetic pattern and sex of mice in experimental paracoccidioidomycosis. Clin. Exp. Immunol., 101: $114-120$

VARGAS-VILLAVICENCIO, J. A., LARRALE, C., LÉON-NAVA, M. A., Morales-Montor, J. (2005): Regulation of immune response to cestode infection by progesterone is due to its metabolism to estradiol. Microbes Infect., 7: 485 - 493 Vasconi, M. D., Malfante, P., Bassi, A., Giudici, C., Revelli, S., Masso, R. D., Font, M. T., Hinricheses, L. (2008): Phenotypic differences on the outcome of the hostparasite relationship: behavior of mice of the CBi stock in natural and experimental infection. Vet. Parasitol., 153: $157-163$

Volcan, G. S., Medrano, C. E., Payares, G. (1992): Experimental heteroxenous cycle of Lagochilascaris minor Leiper, 1909 (Nematoda: Ascarididae), in white mice and cats. Mem. Inst. Oswaldo Cruz, 87: 535 - 532

Wakelin, D., Mitchell, L. A., Donachie, A. M., GRENCIS, R. K. (1986): Genetic control of immunity to Trichinella spiralis in mice. Immunology, 8: $159-170$

ACCEPTED JANUARY 6, 2009 